\title{
Late-20th-century changes in glacier extent in the Caucasus Mountains, Russia/Georgia
}

\author{
Chris R. STOKES, ${ }^{1}$ Stephen D. GURNEY, ${ }^{1}$ Maria SHAHGEDANOVA, ${ }^{1}$ \\ Victor POPOVNIN ${ }^{2}$ \\ ${ }^{1}$ Landscape and Climate Research Group, Department of Geography, The University of Reading, Reading RG6 6AB, UK \\ E-mail: c.r.stokes@reading.ac.uk \\ ${ }^{2}$ Geographical Faculty, Moscow State University, Leninskiye Gory, 119992 Moscow, Russia
}

\begin{abstract}
Glaciers occupy an area of $\sim 1600 \mathrm{~km}^{2}$ in the Caucasus Mountains. There is widespread evidence of retreat since the Little Ice Age, but an up-to-date regional assessment of glacier change is lacking. In this paper, satellite imagery (Landsat Thematic Mapper and Enhanced Thematic Mapper Plus) is used to obtain the terminus position of 113 glaciers in the central Caucasus in 1985 and 2000, using a manual delineation process based on a false-colour composite (bands 5, 4, 3). Measurements reveal that $94 \%$ of the glaciers have retreated, $4 \%$ exhibited no overall change and $2 \%$ advanced. The mean retreat rate equates to $\sim 8 \mathrm{~m} \mathrm{a}^{-1}$, and maximum retreat rates approach $\sim 38 \mathrm{~m} \mathrm{a}^{-1}$. The largest $\left(>10 \mathrm{~km}^{2}\right)$ glaciers retreated twice as much $\left(\sim 12 \mathrm{~m} \mathrm{a}^{-1}\right)$ as the smallest $\left(<1 \mathrm{~km}^{2}\right)$ glaciers $\left(\sim 6 \mathrm{~m} \mathrm{a}^{-1}\right)$, and glaciers at lower elevations generally retreated greater distances. Supraglacial debris cover has increased in association with glacier retreat, and the surface area of bare ice has reduced by $\sim 10 \%$ between 1985 and 2000 . Results are compared to declassified Corona imagery from the 1960s and 1970s and detailed field measurements and mass-balance data for Djankuat glacier, central Caucasus. It is concluded that the decrease in glacier area appears to be primarily driven by increasing temperatures since the 1970s and especially since the mid-1990s. Continued retreat could lead to considerable changes in glacier runoff, with implications for regional water resources.
\end{abstract}

\section{INTRODUCTION}

It is widely acknowledged that glaciers are sensitive to climate change (Houghton and others, 2001). In recent years, several studies have reported increased glacier loss from many regions across the world, and there would appear to be a clear link between glacier retreat and increased global temperatures ('global warming') (Meier, 1984; Oerlemans, 1994, 2005; Arendt and others, 2002; Dyurgerov, 2003). Estimates suggest that the contribution of melting glaciers to sea-level rise may be increasing, accounting for as much as $27 \%$ of sea-level rise for the period 1988-98, compared to only 16\% between 1977 and 1987 (Dyurgerov, 2003). Modelling scenarios up to the year 2050 predict a mean volume loss of $60 \%$ for selected Northern Hemisphere glaciers, confirming that continued warming will lead to an even greater contribution to sea-level rise (Schneeberger and others, 2003). It is increasingly urgent, therefore, to monitor glacier change, in terms of both its impact on global sealevel rise and the implications for water resources at a regional and local scale.

In order to make an accurate assessment of the contribution of glaciers to the global water balance, it is necessary to monitor changes in the areal extent of glaciers, as well as other parameters such as their volume and mass balance. Accurate glacier inventories, however, only exist for around $40 \%$ of the world, and this dataset is biased towards Northern Hemisphere glaciers, especially those in Europe, Canada, the USA and parts of the former Soviet Union (Dyurgerov, 2003). Additionally, very small glaciers are often under-represented in glacier inventories. Although these glaciers only represent a small fraction of the cryosphere, they are very important water resources to local communities, and play a significant role in the water budget of many regions of the world, where their summer melt strongly determines the seasonal runoff regime. Regular monitoring of their behaviour assumes added importance given that smaller glaciers are known to respond more rapidly to climate change (Kaser and others, 2003).

One region where alpine glaciers exist is the Caucasus Mountains, running west-northwest to east-southeast between the Black Sea and the Caspian Sea and separating southwestern Russia from Georgia (Volodicheva, 2002). Glaciers cover an area of around $1600 \mathrm{~km}^{2}$ in the Caucasus (estimates range from 1400 to $1805 \mathrm{~km}^{2}$; Bedford and Barry, 1994), and although mass-balance data for selected individual glaciers exist, an up-to-date regional assessment of glacier change is lacking. There is widespread evidence of glacier recession in this region since the end of the Little Ice Age (LIA; Solomina, 2000), but information concerning the latter stages of the 20th century is limited. Of the few studies that have focused on glacier change in the Caucasus, Bedford and Barry (1994) reported a strong retreat trend for 51 glaciers between 1972 and 1986. This was in marked contrast to glacier change in the European Alps, where the number of glaciers retreating during this period had steadily declined (Wood, 1988).

Remote sensing is an ideal tool for increasing the number of monitored glaciers at the global scale, especially in remote or politically sensitive areas. It has the added advantage of allowing a single user to determine changes in glacier surface characteristics over very large areas (thousands of $\mathrm{km}^{2}$ ), and is extremely rapid when compared to field investigation. Landsat Thematic Mapper (TM) and Enhanced Thematic Mapper Plus (ETM+) are widely recognized as highly valuable for glacier mapping (Bayr 
and others, 1994; Paul, 2000, 2002; Paul and others, 2002). A single scene has a spatial coverage of $180 \mathrm{~km}$ by $180 \mathrm{~km}$, and the high resolution of the sensor $(30 \mathrm{~m} ; 15 \mathrm{~m}$ in the panchromatic band of the ETM+) permits accurate monitoring of small glaciers $\geq 0.1 \mathrm{~km}^{2}$ (Paul and others, 2002). More recent sensors (e.g. the Advanced Spaceborne Thermal Emission and Reflection Radiometer (ASTER)) have a higher spatial resolution, but their relatively recent launch dates preclude direct comparative investigations of glacier changes during the 1980s and 1990s.

In this paper, TM and ETM+ are used to map the terminus position of over 100 glaciers in the central Caucasus, covering a study area of around $20000 \mathrm{~km}^{2}$ and focusing specifically on changes between 1985 and 2000, thereby effectively extending the analysis of Bedford and Barry (1985). Associated changes in the evolution of supraglacial debris during this time period are also assessed and we compare our results with detailed field measurements on Djankuat glacier, taken to be a representative glacier for this region (Haeberli and others, 2003).

The significance of this study is four-fold. Firstly, the response of Russian glaciers to future climate change is uncertain because glacier locations span more than one climatic zone and are influenced by radically different precipitation and temperature regimes (cf. Solomina, 2000). Continued monitoring of glacier behaviour from across Russia is necessary to inform predictions of future climate impacts. Secondly, the Caucasus glaciers are a major water source for the Caspian Sea, and future changes in glacier runoff are likely to impact human activity and development in this important region (Koronkevich, 2002). Thirdly, an extensive mass-balance record (1967 onwards) exists for Djankuat glacier (Popovnin and Naruse, 2005; Shahgedanova and others, 2005), and it has been selected as the representative glacier for the region and one of ten reference glaciers of the world (Haeberli and others, 2003). An overall synthesis of the Caucasus region is therefore necessary to assess the extent to which Djankuat glacier is representative. Lastly, glacier outburst floods and related debris flows are a significant hazard in the Caucasus (Bogatikov and others, 2003; Kotlyakov and others, 2003; Seynova and others, 2003). Remote sensing of changes in glaciated environments is an important tool for assessing and monitoring the potential for glacier hazards (e.g. monitoring the evolution of proglacial lakes (Kääb and others, 2002)).

\section{METHODOLOGY}

Manual delineation of glacier outlines has been widely used (e.g. Rott and Markl, 1989; Williams and others, 1997), but it is generally recognized that semi-automated techniques are far more time-efficient (Paul and others, 2002). The low reflectivity of snow and ice in the middle part of the spectrum allows glacier ice to be detected from a segmented/threshold ratio image of TM bands 4 and 5 (Paul and others, 2002). Although the threshold value can be selected interactively from regions with snow and ice cast in shadow, automated techniques are severely hampered by the presence of supraglacial debris (Paul and others, 2002). As a result, glaciers with debris-covered snouts will often be misrepresented using automated techniques, and manual delineation from a false-colour composite image of TM bands $5,4,3$ (red $(R)$, green $(G)$, blue $(B))$ is recommended
(Paul and others, 2002). Given that many glaciers in the Caucasus are characterized by debris-covered termini (cf. Popovnin and Rozova, 2002), analysis in this paper involves manual delineation of glaciers using a false-colour composite of TM bands 5, 4 and 3 .

To maximize the accuracy and consistency of the mapping, it is necessary to derive glacier changes from comparison of two scenes from the same band combinations and with the same resolution. It is also advantageous to obtain scenes from exactly the same path and row, so that the horizontal errors from topographic distortion are the same. Having selected the path and row for our study area, image selection was guided by the following principles (cf. Paul and others, 2002): (a) the scenes are obtained close to or at the end of the ablation season, minimizing potential complication from seasonal snow accumulation, and (b) scenes are obtained during cloud-free conditions. Imagery was obtained from the Earth Science Data Interface (ESDI) at the Global Land Cover Facility, University of Maryland, MD, USA (http://glcfapp.umiacs.umd.edu:8080/ esdi/index.jsp). Two Landsat scenes (a TM image from August 1985 and an ETM+ image from September 2000) were obtained from path 171 , row 30 , centred on the main Caucasus ridge and covering the conical ice cap on the highest mountain peak, El'brus (5642 m; see Fig. 1). These images were geocorrected and co-registered using ERDAS Imagine 8.7 software with a resampled pixel size of $25 \mathrm{~m}$ on both images. Note that this study region does not cover the entire glacierized area in the Caucasus and that several small ice masses occur to the northwest and southeast of this scene (Fig. 1).

The primary aim of this study is to compare recent changes in the terminus positions of 113 selected glaciers from the mid-1980s to 2000. Glaciers within the study area were selected for measurement on the basis that: (a) they had a discernible glacier tongue/snout fed by a catchment area, and (b) the snout position was readily identifiable on both images in 1985 and 2000. This resulted in all major glaciers within our study area being measured, and only extremely small glaciers or glacierets $<0.05 \mathrm{~km}^{2}$ being omitted.

The first step was to digitize the terminus positions of the 113 selected glaciers (of various sizes) from the study area, through careful manual delineation on the imagery from 1985 and 2000. Snouts were digitized on the imagery at a scale of between 1:30000 and 1:15000. Sensitivity analysis of the digitizing at a scale of $1: 30000$ found the accuracy to be of the order of $\pm 25 \mathrm{~m}$, i.e. the same glacier snout was independently digitized 20 times and the maximum distance between any two digitized snout positions was $\leq 25 \mathrm{~m}$. Once digitized, the difference between the terminus positions in 1985 and 2000 could be accurately measured. Retreat distances for each glacier were added to the glacier attribute data stored in ERDAS Imagine. Glacier size (surface area) and the elevation of the terminus were obtained from Katalog Lednikov SSSR (1967$77,1975-77)$ to allow broad comparisons between the length change data for similar glaciers (i.e. similar size and altitudinal range). This information was then exported to a spreadsheet to calculate descriptive statistics and explore the relationships between mean retreat distance and glacier size, etc.

It is well known that glacier snouts rarely retreat in a uniform manner, and so it is important to denote where the 

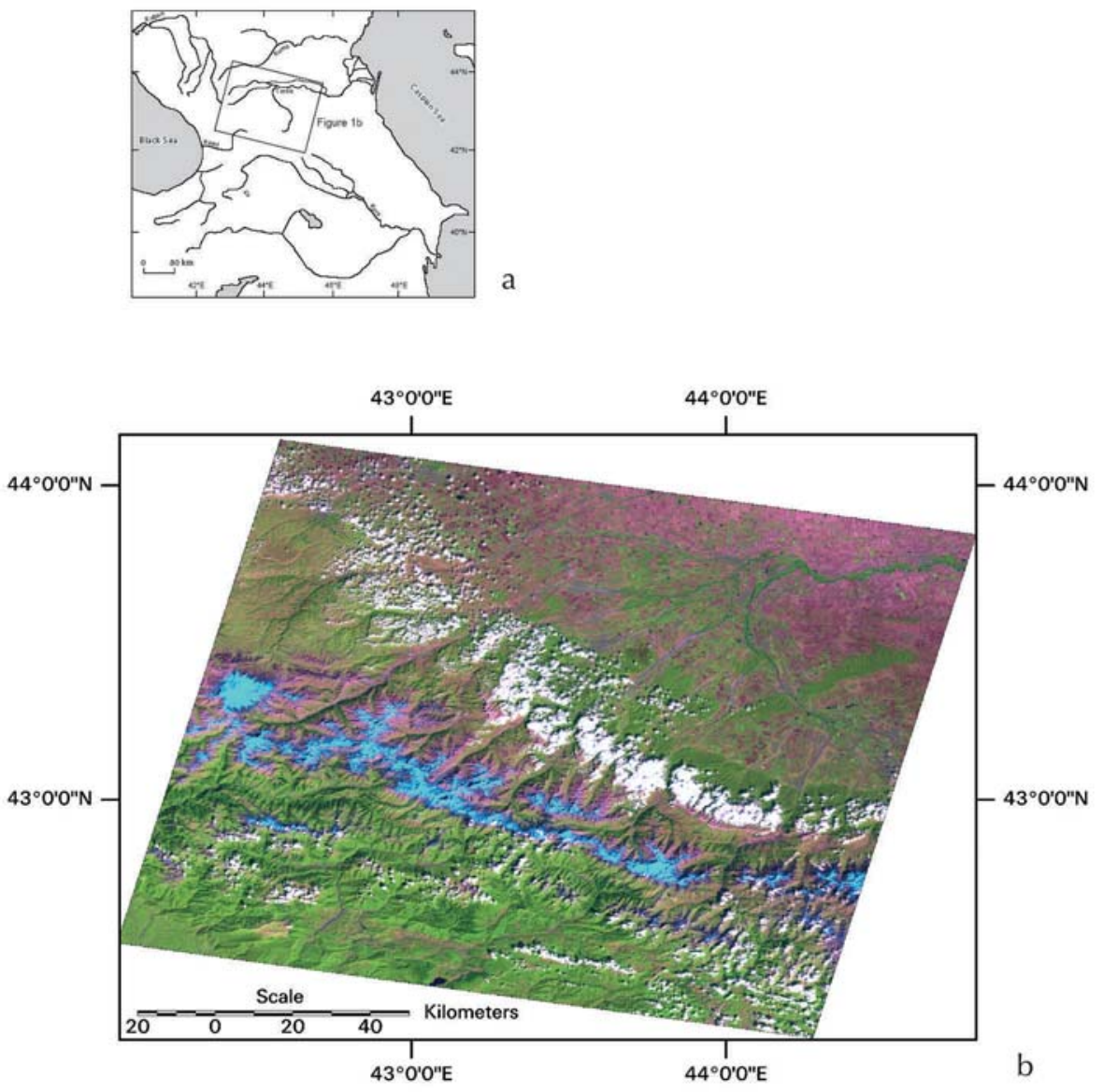

Fig. 1. Location map of the Caucasus Mountains: (a) coverage of the Landsat scenes from path 131, row 30; (b) a false-colour composite image $(5,4,4)$ from 2000 showing the study area, with glacier ice in bright blue and clouds as white.

measurements were taken. To maintain consistency throughout the study area, changes in snout position were measured along the central axis (apex) of the glacier. This often coincided with the distance of greatest retreat, so the measurements presented should be generally viewed as a maximum retreat distance. The panchromatic band of the ETM+ from the 2000 scene (spatial resolution $15 \mathrm{~m}$ ) provided a useful independent check of the snout mapping at the higher multispectral resolution $(25 \mathrm{~m})$.

A further aim of this study is to assess associated changes in the amount of supraglacial debris, known to be a key influence on glacier mass balance and recession in the Caucasus (Popovnin and Rozova, 2002). To this end, the surface area of bare ice, i.e. glacier ice without a continuous covering of supraglacial debris, was digitized and compared between 1985 and 2000. The extent of bare ice was manually delineated from both scenes using the 5, 4, 3 (R, G, B) composite at a scale of around 1:30000. This band combination reveals bare ice as bright blue, and there is a generally sharp transition to supraglacial debris which appears deep purple. It is acknowledged that delineating the boundary between bare ice and debris-covered ice using imagery of this resolution is difficult. Additionally, the measurements only provide two snapshots from 1985 and 2000, and supraglacial debris is likely to fluctuate over much shorter timescales, influenced by interannual variations in accumulation and ablation and non-climatic factors (e.g. rockfalls). To ensure consistency, however, both images were obtained from the end of the ablation season, and analysis was performed using the same band combination. Although the mapping is unlikely to be entirely robust, it does reveal general patterns in the evolution of debris cover across the region, which can be checked against field observations (e.g. Popovnin and Rozova, 2002). Automated techniques might have been much quicker at visualizing the bare-ice extent, but it was important to manually digitize the up-glacier boundaries of the debris-covered ice as accurately as possible in order to assess subtle changes in the extent over time (e.g. the emergence of thin medial moraines may have been beyond the resolution of semi-automated techniques).

Although the study focuses on recent changes in ice extent between 1985 and 2000, several declassified Corona images from the 1960s and 1970s were obtained from the United States Geological Survey (USGS) Earth Resources Observation Center (EROS) (http://edc.usgs.gov/). These images occur at various resolutions but provide a valuable window into the state of a handful of the glaciers in the 1960s and 1970s. In addition, for most glaciers, the maximum LIA limit was clearly revealed by a 'fresh' proglacial zone characterized by an absence of vegetation. In some cases, the proglacial zone was bounded by several large terminal moraines, thought to relate to the maximum advance of glaciers during the 13th century, although later advances are known to have occurred towards the end of the LIA around 1850 (Solomina, 2000). Such information provides a useful context to assess the magnitude of the recent changes which are the focus of this investigation. 


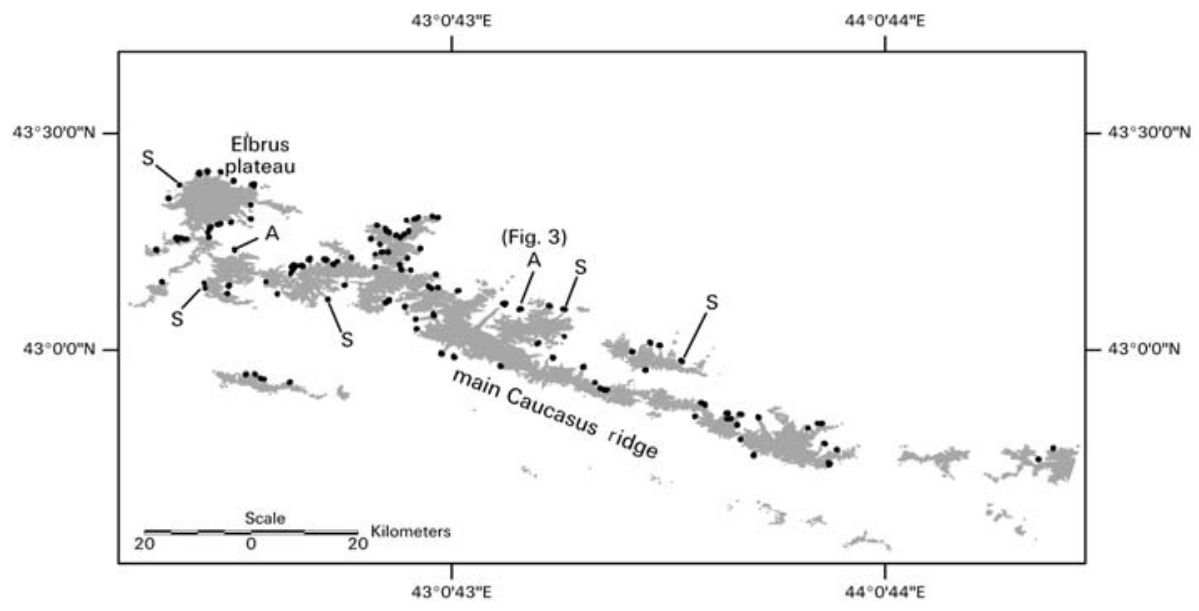

Fig. 2. Map of the central Caucasus showing the extent of debris-free ice in 2000 (grey) and the location of the 113 measured glaciers (black dots).

\section{RESULTS}

\section{Change in glacier terminus position (1985-2000)}

The 5, 4, 3 false-colour composite image proved accurate in determining glacier termini because: (a) proglacial meltwater streams emanating from the snout were clearly visible as bright blue surrounded by pink/purple unvegetated debris, and (b) a drop in elevation at the terminus of a steep snout often cast an obvious shadow that appears darker than the surroundings.

The extent of debris-free ice in the study area in 2000 is shown in Figure 2 (grey), which also indicates the broad geographical spread of the 113 glaciers where terminus positions were measured (black dots). The glaciated area in Figure 2 is estimated at $1260 \mathrm{~km}^{2}$, representing around 80 $90 \%$ of the total glaciated area in the Caucasus (Bedford and Barry, 1994).

Of the 113 glaciers measured, 107 ( 94\%) retreated between 1985 and 2000. Five glaciers appear to have exhibited no overall change ( $4 \%$ : marked ' $\mathrm{S}$ ' in Fig. 2 ) and two glaciers advanced ( $2 \%$ : marked ' $\mathrm{A}$ ' in Fig. 2$)$. These results correlate well with detailed field measurement of the snout position of Djankuat glacier (e.g. Popovnin and Rozova, 2002) and are in agreement with sporadic field measurement and anecdotal evidence from other glaciers (e.g. field investigation confirms that Mizhirgi glacier advanced between 1985 and 2000). The overall advance of Mizhirgi glacier between 1985 and 2000 is shown in Figure 3. The shadow cast by the steep snout and the appearance of the proglacial meltwater stream allows accurate determination of the snout position (Fig. 3a). This glacier advanced by around $108 \pm 25 \mathrm{~m}$ in 15 years. Both glaciers that have advanced are north-facing, but there is no clear geographical pattern which characterizes the advancing or stationary glaciers (Fig. 2). The non-retreating glaciers span a number of different sizes $\left(0.9-11.3 \mathrm{~km}^{2}\right)$ and occur at the full range of glacier elevations in the study area (1850-3309 ma.m.s.l).

The vast majority of the glaciers in the study region retreated. The mean retreat distance was $121 \pm 25 \mathrm{~m}$, equivalent to $8.1 \mathrm{~m} \mathrm{a}^{-1}$ between 1985 and 2000. The maximum retreat distance was $571 \pm 25 \mathrm{~m}$ (retreat rate $=$ $38 \mathrm{~m} \mathrm{a}^{-1}$ ) for Karaugom glacier in the southeast of the study area. Figure 4 shows the frequency distribution of terminus change for all 113 measured glaciers. It can be seen that the majority ( $\sim 70 \%$ ) of glaciers retreated $0-150 \mathrm{~m}$.

The glacier length change data were sorted according to the size of the glaciers. Although there is no statistically significant correlation between glacier size and terminus retreat, the general pattern is that the larger glaciers have retreated further. Figure 5 shows the mean retreat distance for each size class of glacier; it can be seen that glaciers $>10 \mathrm{~km}^{2}$ have retreated almost twice as far as glaciers $<1 \mathrm{~km}^{2}$. It should be remembered, however, that the retreat rate is likely to be more comparable between large and small glaciers if the retreat is calculated as a percentage of overall glacier length.

Glacier length changes were also assessed with respect to the elevation of the glacier snout. Again, although there is no statistically significant relationship for the whole sample, Figure 6 illustrates that glaciers at higher elevations have, in general, retreated less than those at lower elevations. This would be expected if the snouts of glaciers at lower elevations are more sensitive to climatic (temperature?) forcing than those at higher elevations.

The pattern of retreat for six neighbouring glaciers, including Djankuat glacier, is shown in Figure 7, indicating the different response of different-sized glaciers. For example, Shkhelda glacier (furthest west in Fig. 7) retreated around $350 \mathrm{~m}$ between 1985 and 2000, compared to around $30 \mathrm{~m}$ for Djankuat glacier (furthest east in Fig. 7). Indeed, the retreat distance of Shkhelda glacier is the second largest measured in the study area. Its retreat is characteristic of many of the glaciers, in that it appears to be accompanied by a general increase in debris cover migrating up-glacier. A similar situation has been reported from detailed field measurements on Djankuat glacier (Popovnin and Rozova, 2002). The up-ice increase in debris cover on Shkhelda glacier is clearly observable in Figure 8, which shows that debris cover has increased on the feeding tributary glaciers (labelled ' $T$ ' and ' $T 2$ ') and on the main glacier trunk (labelled ' $\mathrm{D}$ '), reducing the amount of bare ice visible at the surface.

The satellite imagery also reveals the inferred maximum LIA limit of Shkhelda glacier (Fig. 8b). This limit is taken to be the 'fresh' unvegetated proglacial zone in front of the 

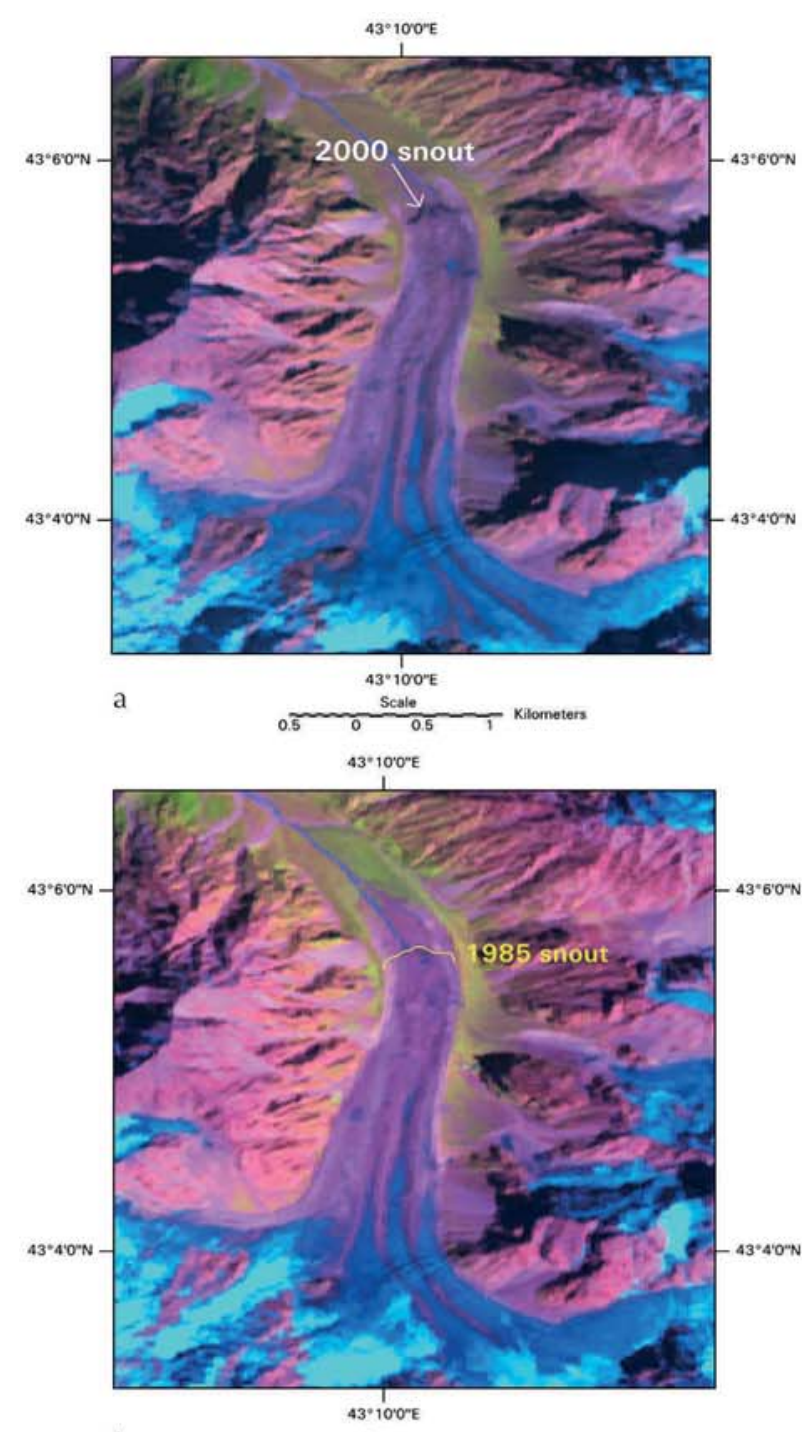

b

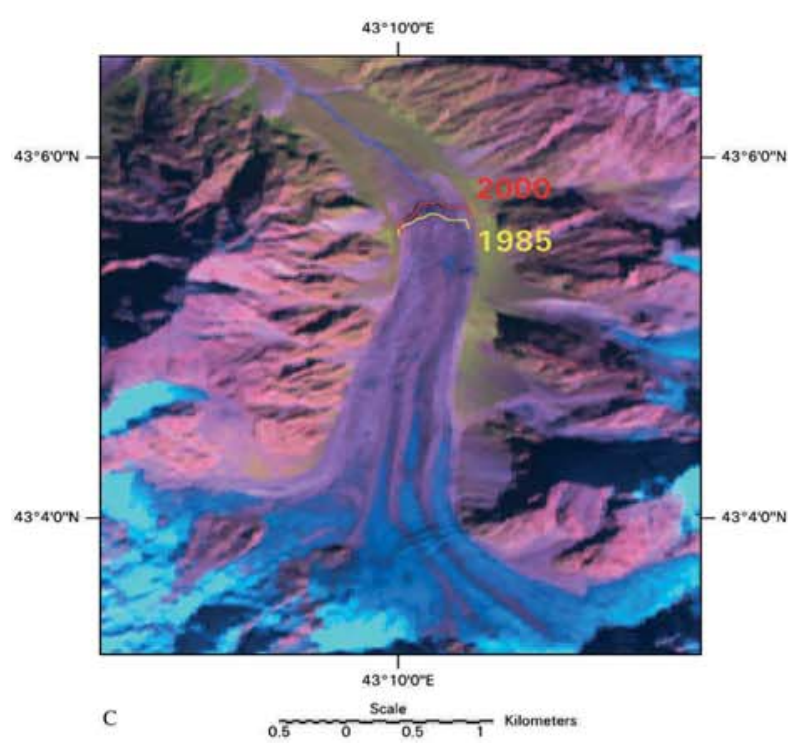

Fig. 3. Landsat satellite imagery $(5,4,3$ : R, G, B) showing the advance of Mizhirgi glacier, 1985-2000. (a) In 2000, the snout position is clearly visible because of the shadow and the bright blue appearance of the proglacial stream. (b) In 1985, the meltwater stream emanates from a different position at the terminus. (c) With the two snout positions overlaid, it is clearly seen that the snout has advanced by $110 \pm 25 \mathrm{~m}$. This is one of only two glaciers from the 113 sampled showing an overall advance between 1985 and 2000 .

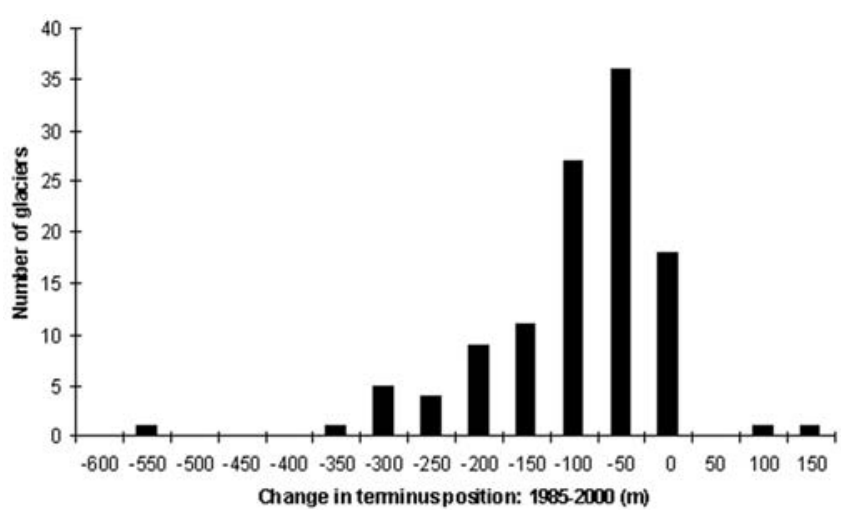

Fig. 4. Frequency distribution of terminus change for 113 selected glaciers in the central Caucasus.

snout (pink/purple colours), which appears in marked contrast to adjacent vegetated areas which appear as bright green (Fig. 8). Although the timing of the LIA limit in the Caucasus is complex (see Solomina, 2000), the glacier has retreated around $1300 \mathrm{~m}$ from the LIA maximum extent. Around $350 \mathrm{~m}$ of this retreat $(>25 \%)$ has occurred since 1985. For those glaciers where a clear LIA limit can be easily determined on the satellite imagery $(n=72)$, the mean percentage of post-LIA retreat accomplished between 1985 and 2000 is $15 \%$.

The pattern of glacier loss towards the end of the 20th century is further emphasized by the Corona imagery from the 1960s. Figure 9 compares the position of Tsanner glacier on a Corona image from August 1964 with that of the ETM+ scene in 2000. Although the resolution of the Corona imagery does not allow accurate measurement of the glacier snout (and is somewhat distorted), it can be clearly seen that the glacier tongue has changed its configuration and has narrowed and retreated from its position in 1964. The 1964 scene also shows the formation of a medial moraine where a smaller tributary glacier feeds the main east-to-west flow. In 2000, however, it would appear that this smaller glacier (renamed north Tsanner glacier) is no longer contributing ice to Tsanner glacier. The Corona imagery confirms that the retreat between 1985 and 2000 is not anomalous but is part of an overall phase of glacier retreat since the 1960s and 1970s. This conclusion is supported by evidence of widespread retreat between 1972 and 1986 as reported by Bedford and Barry (1994).

\section{Change in the distribution of supraglacial debris cover (1985-2000)}

Supraglacial debris cover is known to have an important influence on glacier mass balance primarily through its influence on ablation (Benn and Evans, 1998). A secondary aim of this study, therefore, is to assess the changes in the evolution of debris cover on Caucasus glaciers. To this end, the extent of debris-free ice was mapped in 1985 and 2000. Figure 10 shows the change in the areal extent of debris-free ice between 1985 and 2000, indicating that a marked reduction has taken place throughout the study area (coloured red). This measurement, like the terminus position measurement, is subject to a small error, but this was minimized by manual delineation of the boundary between debris-free and debris-covered ice and is largely insignificant given the total glaciated area is $>1000 \mathrm{~km}^{2}$ (see 


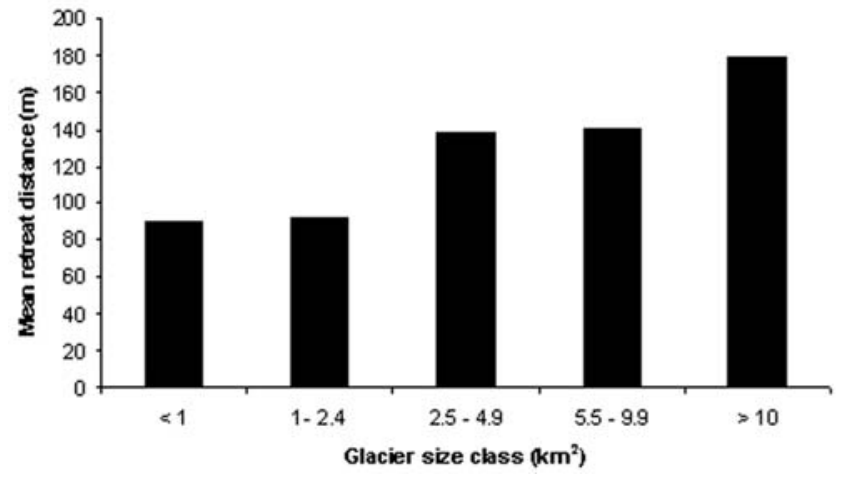

Fig. 5. Mean retreat distance for different-sized glaciers in the central Caucasus.

Fig. 10). This preliminary analysis indicates that the area of debris-free ice was $\sim 1260 \mathrm{~km}^{2}$ in 1985 but decreased to $\sim 1136 \mathrm{~km}^{2}$ in 2000 , an approximate decrease of $\sim 10 \%$ in 15 years.

It could be the case that the decrease in extent of debrisfree ice is solely related to an increase in debris cover and that the extent of the glaciers has remained unchanged. However, glacier retreat has also occurred on the relatively debris-free glaciers which drain the northern portion of the conical ice cap on Gora El'brus (shown in Fig. 10b-d). These glaciers generally lack the debris mantle typical of the glaciers flowing through steep-sided valleys, and the reduction in bare ice in this area is only a result of deglaciation. Thus, although we have no quantitative measurements of the change in the percentage area of debris-covered ice between 1985 and 2000, our observations indicate that the $\sim 10 \%$ decrease in bare ice is attributable to both an increase in debris cover and glacier retreat.

\section{DISCUSSION}

\section{Glacier retreat and climatic warming}

Many studies from around the world have reported increased glacier loss in conjunction with increased global

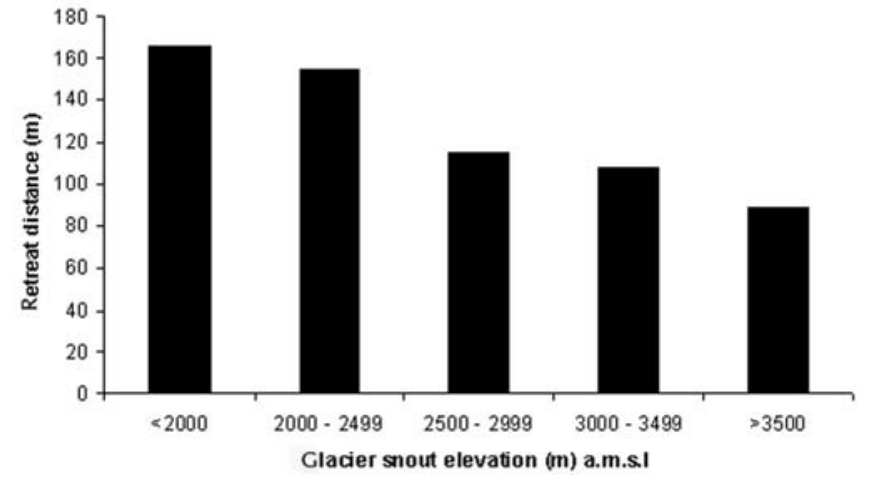

Fig. 6. Mean retreat distance for glaciers at different elevations in the central Caucasus.

temperatures during the latter decades of the 20th century (Oerlemans, 1994; Arendt and others, 2002; Francou and others, 2003). Our analysis would appear to suggest that Caucasus glaciers have undergone a similar pattern of retreat in recent decades. The significance of these changes, however, can only be assessed with reference to longerterm fluctuations.

Solomina (1999, 2000) estimated the magnitude of glacier retreat from the LIA maximum to the second half of the 20th century (1950s-1980s) in the former Soviet Union. These data were based on aerial photographs and chronosequences of vegetation development on LIA moraines. In the Caucasus, the dating of LIA moraines is complicated by the fact that there appear to be two broad age ranges: $\sim$ AD 1300 and $\sim A D 1700$ (Serebryannyy and others, 1984, cited in Solomina, 2000, fig. 2). Nevertheless, Solomina (2000) estimated that Caucasus glaciers had retreated, on average, around $611 \mathrm{~m}$ (max. $2800 \mathrm{~m}$ and min. $150 \mathrm{~m}$ ) from the end of the 19th century to the mid20th century.

Bedford and Barry (1994) reported that Caucasus glaciers were generally retreating between the 1960s and 1980s. This is in contrast to the global dataset, albeit dominated by glaciers in the European Alps (Wood, 1988), which shows a trend towards glacier advance through the 1960s to 1981

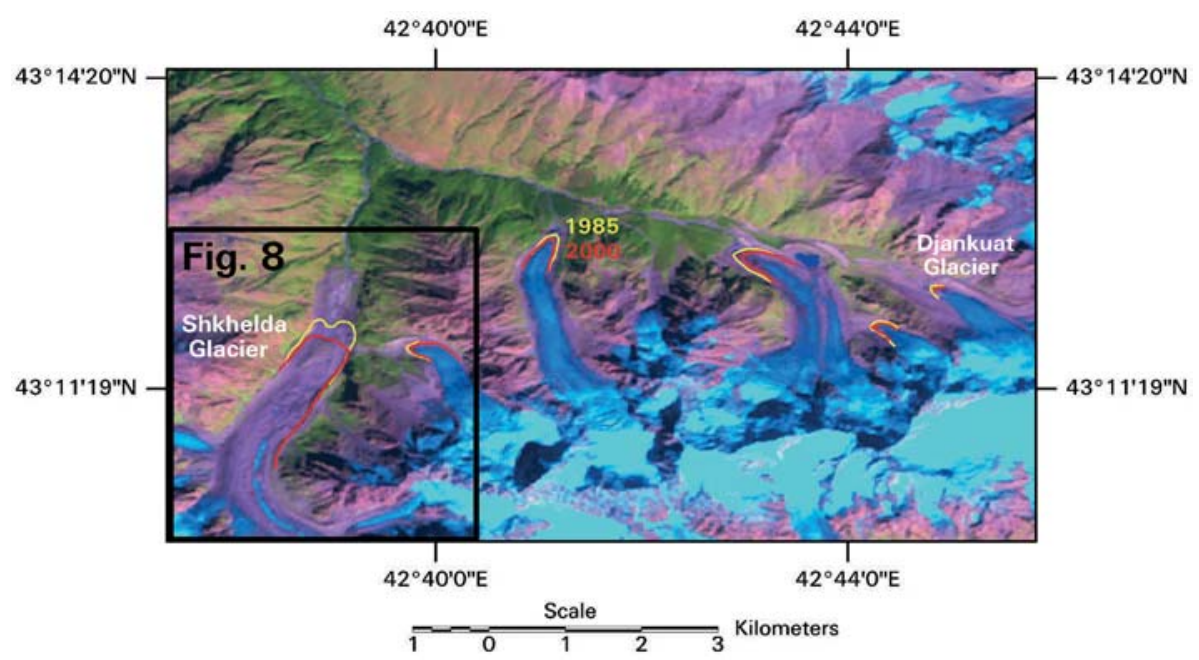

Fig. 7. Retreat for six neighbouring glaciers in the central Caucasus between 1985 (yellow) and 2000 (red), including Djankuat glacier (furthest east), which has an extensive mass-balance record. Also note the location of Shkhelda glacier (furthest west) which exhibits one of the largest retreat rates in the region. 


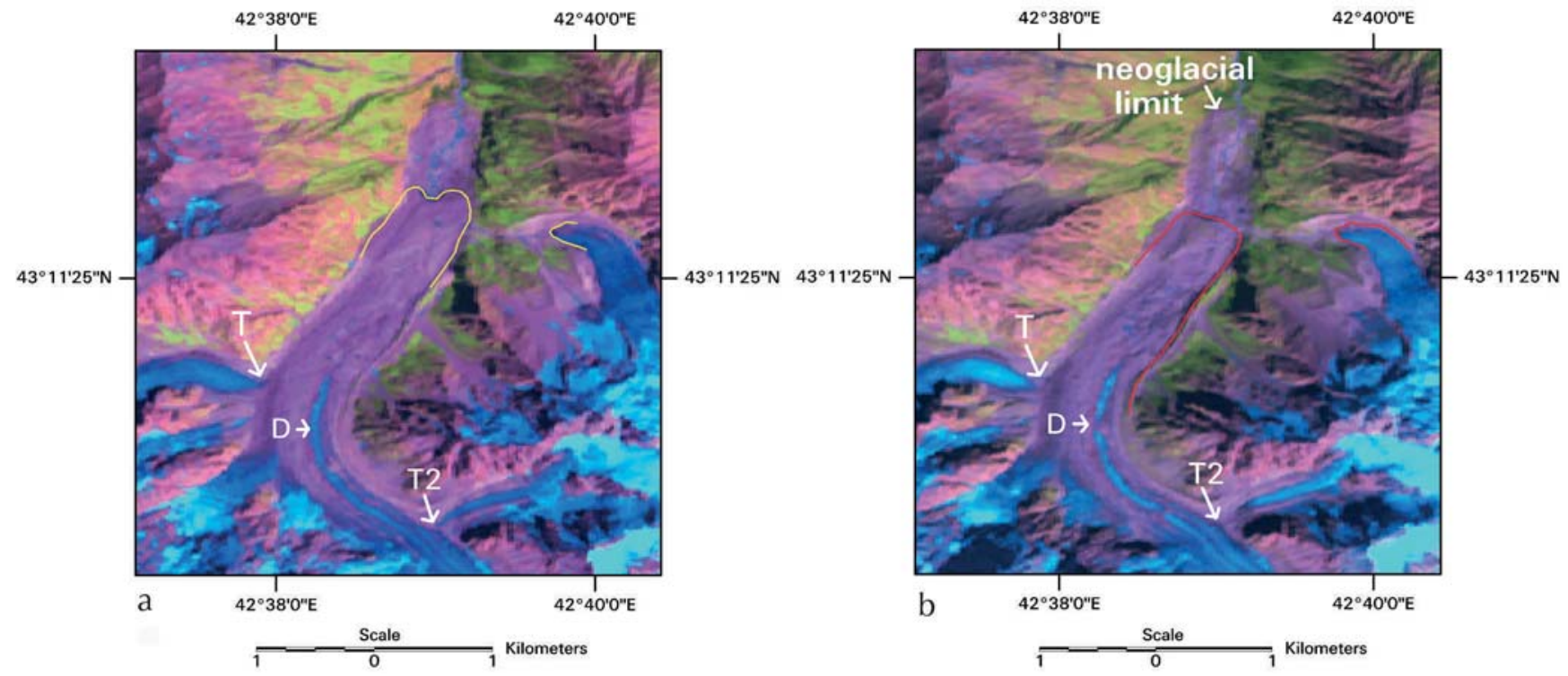

Fig. 8. Increase in debris cover on Shkhelda glacier during terminus retreat. (a) The terminus position in 1985, clearly marked by the emergence of the meltwater stream at an indent at the snout. (b) The emergence of the same stream marks the terminus position in 2000 , approximately $350 \mathrm{~m}$ back from the 1985 position. This retreat is accompanied by an increase in debris cover on the feeding tributaries (cf. ' $\mathrm{T}$ ' and ' $\mathrm{T} 2$ ' in (a) and (b)) and in the centre of the glacier (cf. ' $\mathrm{D}$ ' in (a) and (b)). The zone of unvegetated debris in the proglacial area (pink) marks the LIA limit.

(Bedford and Barry, 1994). The data presented here extend the analysis of Bedford and Barry (1994) and indicate that the retreat trend has continued throughout the 1980s and 1990s. It should be noted, however, that the period from the late 1980s to the early 1990s was relatively favourable for Caucasus glaciers and that retreat rates have greatly accelerated since the mid-1990s.

We also note that seasonal average temperatures at Terskol (Shahgedanova and others, 2005), central Caucasus, show a general decrease from the 1950s to the mid-1970s and then begin to increase from the mid-1970s (see Fig. 11). This suggests that the retreat of Caucasus glaciers from the mid-1970s to 2000 (this paper) correlates well with the temperature record. Shahgedanova and others (2005) note that recent temperature increases during the ablation season on Djankuat glacier have not been compensated for by increases in winter precipitation and accumulation. Indeed, the strong warming signal that has emerged since the mid-1990s has led to a significant increase in summer melt during the ablation season. The decrease in glacier length reported in this paper, therefore, appears to be primarily driven by increasing temperatures since the 1970s and especially since the mid-1990s (Shahgedanova and others, 2005). Analysis of the monthly temperature record at Terskol indicates that the mean annual retreat rate of $8.1 \mathrm{~m}$ between 1985 and 2000 corresponds to an annual increase of $0.1^{\circ} \mathrm{C}$ in the ablation season temperature. This is in broad agreement with the notion that recent changes in glacier length are a reliable indicator of global warming (Oerlemans, 1994, 2005).

\section{Evolution of debris cover on Caucasus glaciers}

Debris cover on a glacier's snout can influence the rate of ablation in two main ways. A thin layer of debris (generally $<1-2 \mathrm{~cm}$ ) will lower the albedo and absorb more shortwave radiation than bare ice. This results in an increase in ablation

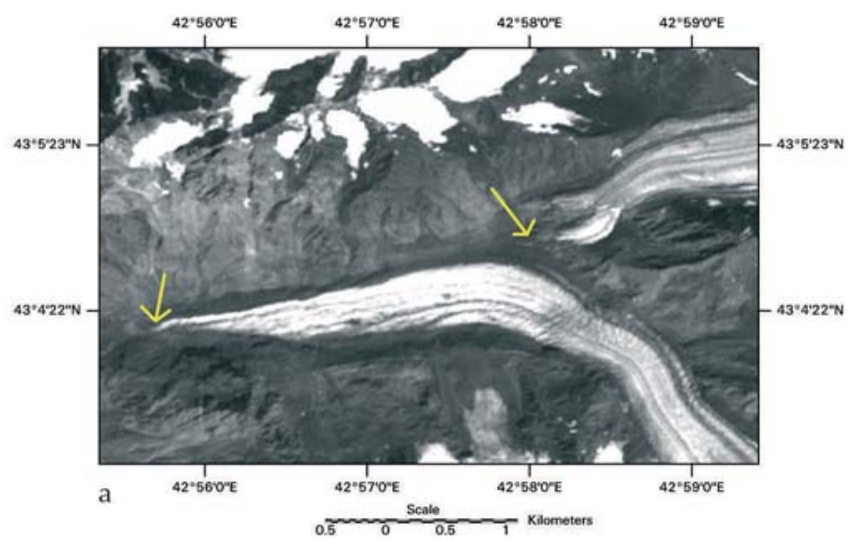

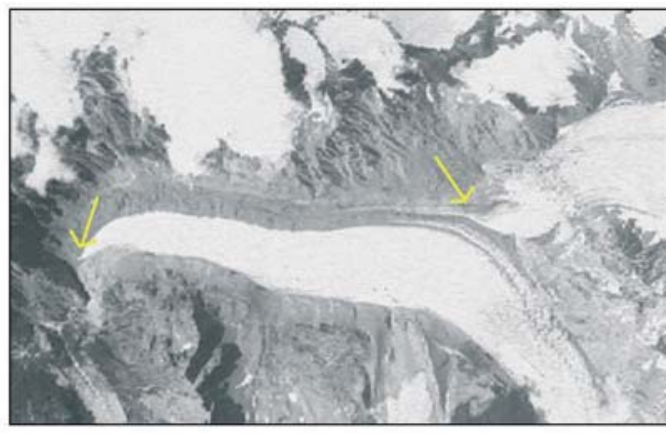

b

Fig. 9. Change in the configuration of Tsanner glacier between 1964 (b) and 2000 (a). Corona imagery provides information from the 1960 s. In this case, the glacier has retreated and narrowed at the snout (see (a)). Also note the active formation of a medial moraine in 1964 . In 2000 , this tributary is no longer contributing ice to the main trunk glacier. 

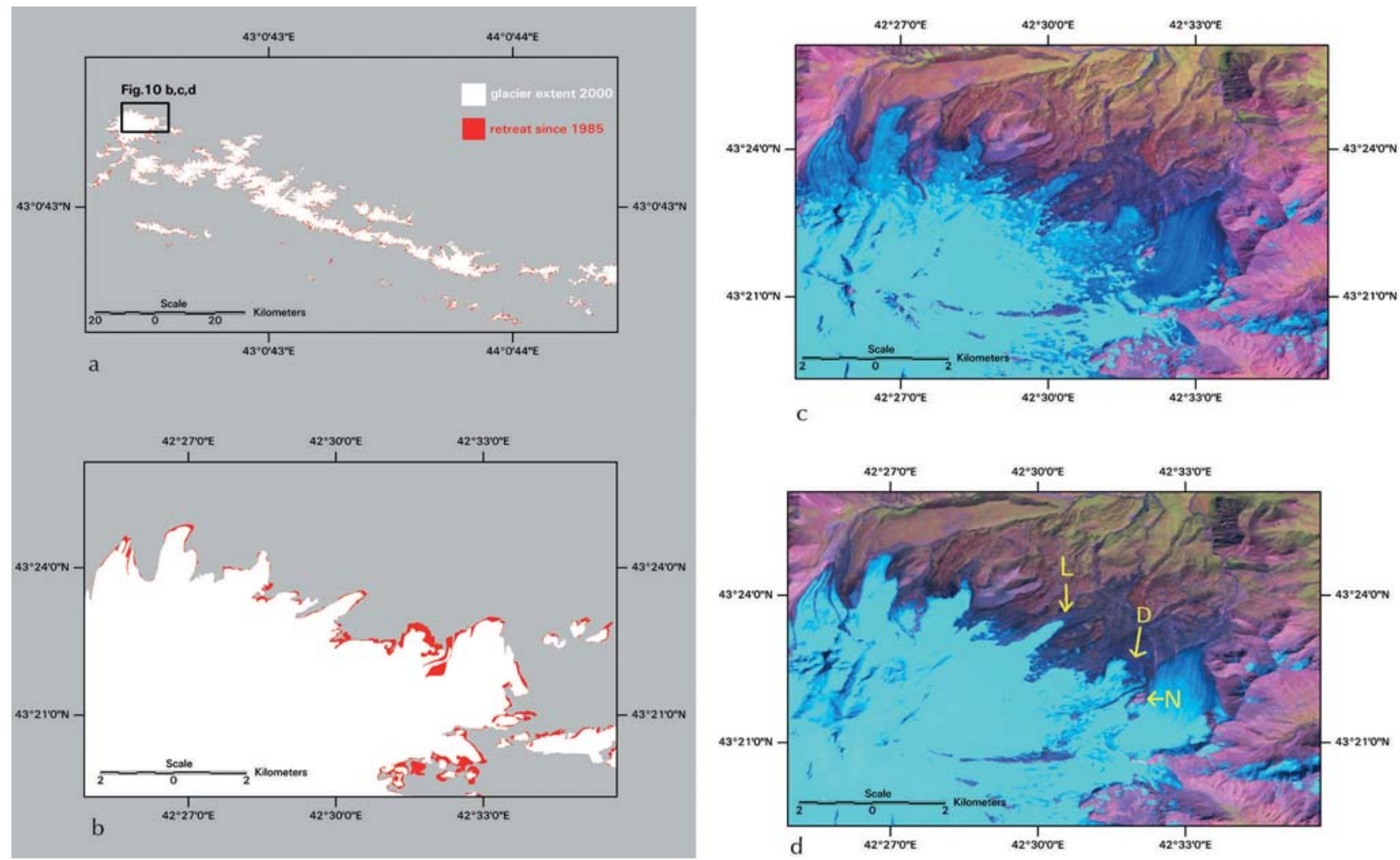

Fig. 10. Change in the areal extent of bare ice, 1985-2000. (a) The red areas denote the loss of bare ice since 1985 ( 10\%). (b) This reduction is clearly seen on the glaciers draining the northern margin of the El'brus volcanic cone. (c, d) These glaciers are generally debrisfree and it can be seen that retreat has been quite rapid in places (see ' $\mathrm{D}^{\prime}$ ). Also note the increase in area of a large nunatak $\left(\mathrm{N}^{\prime}\right.$ ). Deglaciation has also led to the development of small proglacial lakes (see ' $\mathrm{L}$ ') which may lead to the realization of further geohazards in the Caucasus.

of the underlying and adjacent ice (Bozhinskiy and others, 1986; Benn and Evans, 1998). When debris thickness increases (>5-10 mm), however, it has the effect of shielding the underlying ice from incoming solar radiation and greatly reduces ablation (cf. Østrem, 1959; Nakawo and Young, 1982). Thus, thin patchy debris will generally increase ablation, and thick, continuous debris cover will reduce ablation. Benn and Evans (1998) state that where debris cover on glacier tongues is thick and continuous, such as in many high mountain environments, ablation at the snout can be greatly reduced and is often confined to the steeper slopes up-glacier. The result is that ablation is focused on the steeper slopes and the glacier retreats through a process known as 'backwasting'. It is also known that the presence of a thick debris mantle may decouple the glacier from climatic forcing such that debris-covered glaciers respond more slowly to climatic changes (Benn and Evans, 1998). In addition, debris-covered snouts can become separated from more rapidly ablating ice further up-glacier and eventually stagnate and waste away in situ.

The analysis presented here indicates that the surface area of debris-free ice has decreased by around $10 \%$ between 1985 and 2000 (Fig. 10). This reduction appears to be attributable to both glacier retreat (e.g. Fig. 10) and an increase in debris cover (e.g. Fig. 8). This conclusion is supported by field measurements on Djankuat glacier, which indicate that the total area of debris cover increased from $3 \%$ to $10 \%$ of the entire glacier area between 1968 and 1999 during glacier retreat (Popovnin and Rozova, 2002). Furthermore, a general pattern was detected whereby the more negative the mass balance, the higher the rate of debris accumulation. Our analysis suggests that this pattern is typical of Caucasus glaciers as a whole: they are retreating, and supraglacial debris is increasing. This is not surprising given that a characteristic of retreating glaciers is the formation of supraglacial debris from thinning at the snout and the areal melt-out of debris from within the glacier body (Popovnin and Rozova, 2002). What is more interesting is that the shielding effect of the increased supraglacial debris on Caucasus glaciers is not enough to offset the widespread retreat of their termini. Conversely, it could be argued that the debris cover is preventing what would otherwise be an even more rapid retreat. Exploration of the relationship between debris-cover thickness, mass balance and frontal variations is clearly warranted in the future.

\section{Comparison of remote-sensing results with Djankuat glacier field measurements}

Djankuat glacier is a small northwest-facing temperate valley glacier around $3 \mathrm{~km}^{2}$. Located at $43^{\circ} 12^{\prime} \mathrm{N}, 42^{\circ} 46^{\prime} \mathrm{E}$, it lies at an elevation of 2700-3900 m on the main Caucasus ridge and delivers meltwater to the Caspian Sea via the Adylsu, Baksan, Malka and Terek rivers. It is one of the most extensively studied Russian glaciers and has an uninterrupted directly measured mass-balance record going back to 1967 (Dyurgerov and Popovnin, 1988; Shahgedanova and others, 2005). For this reason, the World Glacier Monitoring Service chose it as one of ten reference glaciers of the world (Haeberli and others, 2003). 

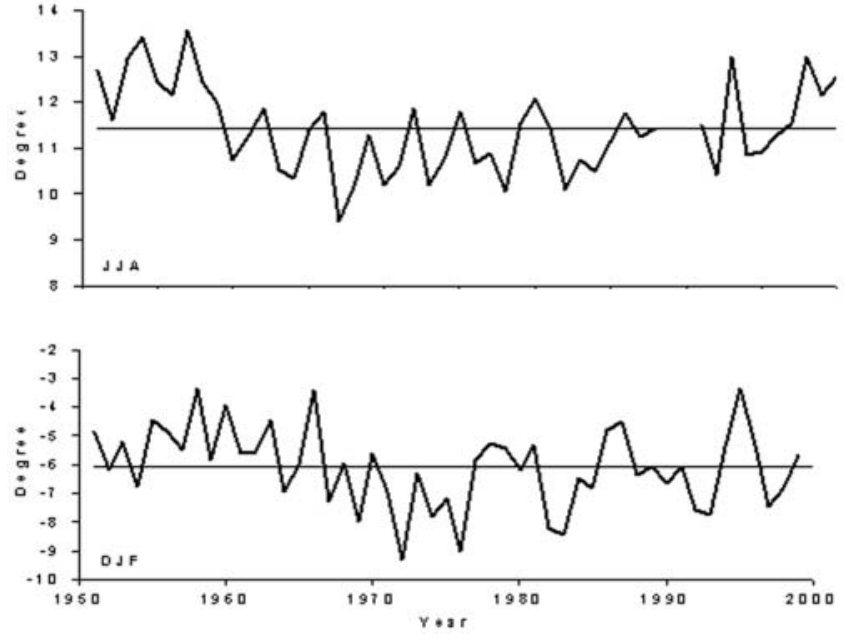

Fig. 11. Time series of seasonal average temperatures $\left({ }^{\circ} \mathrm{C}\right)$ for Terskol (modified from Shahgedanova and others, 2005). Solid lines show long-term average (1951-2001). Terskol is situated in the central Caucasus $\left(43^{\circ} 15^{\prime} \mathrm{N}, 42^{\circ} 31^{\prime} \mathrm{E}\right)$, approximately $7 \mathrm{~km}$ southwest of the margin of the El'brus conical ice cap and at an altitude of $2141 \mathrm{~m}$.

Like most other Caucasus glaciers, Djankuat has retreated significantly during the 20th century. Photographic archives show a retreat of approximately 400 m between $\sim 1930$ and 1996 (Aleynikov and others, 2002a). The terminus remained quasi-stationary in the 1980s, however, despite several years of negative mass balance between 1981 and 1986. In recent years (mid-1990s onwards), a retreat trend appears to have emerged, which has been matched by an increasingly negative mass balance (Popovnin and Naruse, 2005; see Fig.12). Field observations suggest a retreat of around $25 \mathrm{~m}$ between 1985 and 2000. This compares well with our independent measurement of $30 \pm 25 \mathrm{~m}$ from the Landsat satellite imagery.

Djankuat glacier has retreated much less than most of the other glaciers in this study (ranked at 102 out of 113). Its mean annual retreat rate of $\sim 2 \mathrm{~m} \mathrm{a}^{-1}$ contrasts with the mean annual retreat rate of $>8 \mathrm{~m} \mathrm{a}^{-1}$ for all the glaciers measured between 1985 and 2000. Moreover, glaciers of a similar size to Djankuat glacier $\left(2.5-4.9 \mathrm{~km}^{2}\right)$ have a mean retreat distance of $\sim 138 \mathrm{~m}$ between 1985 and 2000, much greater than the $30 \mathrm{~m}$ observed at this glacier (Fig. 5). Glaciers at a similar elevation (2500-2999 ma.m.s.l.) have also, on average, retreated much further $(\sim 115 \mathrm{~m})$ than Djankuat glacier (Fig. 6).

A possible explanation for the low retreat rate may relate to the morphological pecularity of the Djankuat glacier catchment area. This lies partly on the Djantugan firn plateau which rests on the crestal zone of the main Caucasus ridge and serves as a source of ice to glaciers on both sides of the ridge. Recently, it has been observed (Popovnin, 1995; Aleynikov and others, 2002b) that the ice divide on the crestal zone of the Djantugan plateau is migrating south, enlarging the Djankuat glacier catchment area. This recent increase in the accumulation area of the glacier is not incorporated in the mass-balance calculations. As a result, the glacier mass balance is likely to be less negative than has been calculated. Moreover, Aleynikov and others (2002a) note that there is a pulse-like entry of ice into the glacier tongue from the Djantugan plateau, resulting from ice

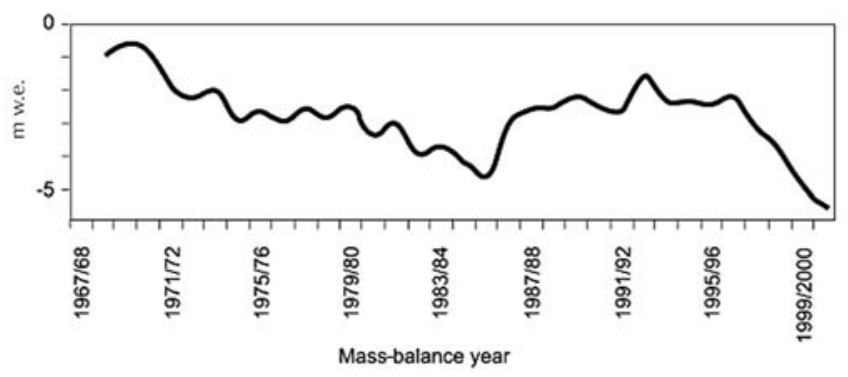

Fig. 12. Cumulative mass balance of Djankuat glacier (see also Shahgedanova and others, 2005).

damming at a narrow passage above an icefall. They suggest that the process of ice flow from the catchment area may resemble that of 'mini-surges' which are transmitted to the glacier snout as kinematic waves (cf. Zolotaryov and others, 1997). As such, the response of the glacier to atmospheric forcing may be non-linear over short timescales. It should also be noted that Popovnin (1996) found that fluctuations of Djankuat glacier appeared to be more pronounced in the upper regions than near the terminus. He notes that ice cover on the steep revetment is thin, and complete melting away of parts of the glacier leads to dramatic changes in glacier surface area.

A further possible explanation for the low retreat rate of Djankuat glacier compared to other glaciers might be related to the increased shielding effect of supraglacial debris near the snout, which has generally thickened in recent years (Popovnin and Rozova, 2002). It should be noted, however, that other glaciers with a continuous debris cover have retreated much greater distances during the observation period (see Fig. 6).

\section{CONCLUSIONS}

Current concerns over anthropogenic climate change make it increasingly urgent to monitor glaciers and evaluate their impact on sea level and regional water resources. This paper utilizes Landsat satellite imagery and reports changes in the terminus position of 113 selected glaciers in the Caucasus between 1985 and 2000. The vast majority ( 94\%) of the glaciers have retreated since 1985, with a mean retreat distance of $121 \mathrm{~m}\left(8.1 \mathrm{~m} \mathrm{a}^{-1}\right)$. Grouping of glaciers with respect to their size indicates that the largest glaciers $\left(>10 \mathrm{~km}^{2}\right)$ have retreated more than twice as far as the smallest glaciers $\left(<1 \mathrm{~km}^{2}\right)$, with mean retreat distances of $\sim 179$ and $\sim 89 \mathrm{~m}$, respectively. In addition, glaciers at lower elevations have retreated further than those at higher elevations. In some cases, the retreat distance of individual glaciers represents a significant $(\sim 25 \%)$ proportion of their overall retreat since the inferred LIA limit. This suggests that glacier loss has increased towards the end of the 20th century and is in accordance with temperature records in the Caucasus that reveal a warming trend since the 1970s and particularly since the mid-1990s (cf. Shahgedanova and others, 2005).

Remote-sensing and field observations indicate that glacier retreat has been accompanied by an increase in debris cover, and our analysis indicates that the areal extent of debris-free ice has reduced by around $10 \%$ between 1985 and 2000. This reduction is not solely attributable to the increase in debris cover, since observations reveal that 
debris-free glaciers have retreated. The increase in debris cover is likely a result of glacier thinning and the melt-out of debris from within the glacier body. We note that the shielding effect of the increased debris cover is not enough to compensate for the widespread retreat of glacier termini. The effect of the debris cover, however, may have been to reduce what would otherwise have been a greater extent of glacier retreat.

The results presented here have been compared to detailed field measurements of the frontal variations, debris cover and mass balance of Djankuat glacier, selected as the representative glacier for the Caucasus and one of ten reference glaciers of the world (Haeberli and others, 2003). These comparisons reveal that the behaviour of Djankuat glacier broadly matches the characteristics of other glaciers in the region: debris cover has increased and the glacier has retreated, although at a much lesser rate than glaciers of a similar size and elevation. It is argued that this is due to local factors relating to the glacier's configuration.

The widespread, and apparently increasing, decline of Caucasus glaciers holds important implications for regional water resources. Runoff from Caucasus glaciers represents a major source for the Caspian Sea, and future changes in glacier area are likely to impact human activity and development in this economically important region.

\section{ACKNOWLEDGEMENTS}

This research was funded by the School of Human and Environmental Sciences at The University of Reading. The ongoing field monitoring of Djankuat glacier is supported by the Russian Foundation for Fundamental Research (03-0564973a; 06-05-64094a). We thank J. Glen (Scientific Editor), R. Barry and an anonymous reviewer for constructive comments.

\section{REFERENCES}

Aleynikov, A.A., V. Popovnin, K. Voytkovskiy and Ye.A. Zolotaryov. 2002a. Indirect estimation of the Djankuat Glacier based on surface topography. Nord. Hydrol., 33(1), 95-110.

Aleynikov, A.A., Ye.A. Zolotaryov and V.V. Popovnin. 2002b. Raspoznavaniye ledorazdela na peremyotnykh lednikovykh complexakh (Dzhantuganskoye plato na Kavkaze) [lce divide recognition on twinned glaciers: a case of the Djantugan firn plateau in the Caucasus]. Vestnik Moskovskogo Universiteta [Moscow Univ. Herald], ser. 5, no. 3, 36-43.

Arendt, A.A., K.A. Echelmeyer, W.D. Harrison, C.S. Lingle and V.B. Valentine. 2002. Rapid wastage of Alaska glaciers and their contribution to rising sea level. Science, 297(5580), 382-386.

Bayr, K.J., D.K. Hall and W.M. Kovalick. 1994. Observations on glaciers in the eastern Austrian Alps using satellite data. Int. J. Remote Sensing, 15(9), 1733-1752.

Bedford, D.P. and R.G. Barry. 1994. Glacier trends in the Caucasus, 1960s to 1980s. Phys. Geogr., 15(5), 414-424.

Benn, D.I. and D.J.A. Evans. 1998. Glaciers and glaciation. London, Arnold.

Bogatikov, O.A. and 7 others. 2003. Catastrophic rock-ice collapse and rapid shove of the Kukurtli Glacier (Elbrus Volcano, Northern Caucasus) in first and second centuries. Doklady Earth Sciences, 391(5), 627-630.

Bozhinskiy, A.N., M.S. Krass and V.V. Popovnin. 1986. Role of debris cover in the thermal physics of glaciers. J. Glaciol., 32(111), 255-266.
Dyurgerov, M.B. 2003. Mountain and subpolar glaciers show an increase in sensitivity to climate warming and intensification of the water cycle. J. Hydrol., 282(1-4), 164-176.

Dyurgerov, M.B. and V.V. Popovnin. 1988. Reconstruction of mass balance, spatial position, and liquid discharge of Dzhankuat glacier since the second half of the 19th century. In Data of glaciological studies. Vol. 40. Rotterdam, A.A. Balkema; New Delhi, Oxonian Press Pvt. Ltd, 111-126. (Russian Translations Series 67.)

Francou, B., M. Vuille, P. Wagnon, J. Mendoza and J.E. Sicart. 2003. Tropical climate change recorded by a glacier in the central Andes during the last decades of the twentieth century: Chacaltaya, Bolivia, $16^{\circ} \mathrm{S}$. J. Geophys. Res., 108(D5), 4154. (10.1029/2002JD002959.)

Haeberli, W., R. Frauenfelder, M. Hoelzle and M. Zemp, eds. 2003. Glacier Mass Balance Bulletin No.7 (2000-2001). Zürich, World Glacier Monitoring Service.

Houghton, J.T. and 58 others, eds. 2001. Climate change 2001: the scientific basis. Contribution of Working Group I to the Third Assessment Report of the Intergovernmental Panel on Climate Change. Cambridge, etc., Cambridge University Press.

Kääb, A. and 6 others. 2002. Glacier monitoring from ASTER imagery: accuracy and applications. In Proceedings of EARSeL LISSIG Workshop, Observing our Cryosphere from Space, March 11-13, 2002, Bern, Switzerland. Paris, European Association of Remote-Sensing Laboratories Special Interest Group Land Ice and Snow, 44-53.

Kaser, G., I. Juen, C. Georges, J. Gomez and W. Tamayo. 2003. The impact of glaciers on the runoff and the reconstruction of mass balance history from hydrological data in the tropical Cordillera Blanca, Peru. J. Hydrol., 282, 130-144.

Katalog Lednikov SSSR. 1967-77. Volume 8. The Northern Caucasus. Leningrad, Gidrometeoizdat.

Katalog Lednikov SSSR. 1975-77. Volume 9. Transcaucasia and Dagestan. Leningrad, Gidrometeoizdat.

Koronkevich, N. 2002. Rivers, lakes, inland seas, and wetlands. In Shahgedanova, M., ed. The physical geography of Northern Eurasia. Oxford, Oxford University Press, 122-148.

Kotlyakov, V.M., O.V. Rototaeva, L.V. Desinov and N.I. Osokin. 2003. Causes and consequences of the catastrophic advance of the Kolka surging glacier in the central Caucasus. Doklady Earth Sciences, 389A(3), 447-451.

Meier, M.F. 1984. Contribution of small glaciers to global sea level. Science, 226(4681), 1418-1421.

Nakawo, M. and G.J. Young. 1982. Estimate of glacier ablation under a debris layer from surface temperature and meteorological variables. J. Glaciol., 28(98), 29-34.

Oerlemans, J. 1994. Quantifying global warming from the retreat of glaciers. Science, 264(5156), 243-245.

Oerlemans, J. 2005. Extracting a climate signal from 169 glacier records. Science, 308, 675-677.

Østrem, G. 1959. Ice melting under a thin layer of moraine, and the existence of ice cores in moraine ridges. Geogr. Ann., 41(4), 228-230.

Paul, F. 2000. Evaluation of different methods for glacier mapping using Landsat TM. In Proceedings of EARSeL SIG Workshop, Land Ice and Snow, June 16-17, 2000, Dresden, Germany. Paris, European Association of Remote-Sensing Laboratories Special Interest Group Land Ice and Snow, 239-245.

Paul, F. 2002. Changes in glacier area in Tyrol, Austria, between 1969 and 1992 derived from Landsat TM and Austrian glacier inventory data. Int. J. Remote Sensing, 23(4), 787-799.

Paul, F., C. Huggel, A. Kääb, T. Kellenberger and M. Maisch. 2002. Comparison of TM-derived glacier areas with higher resolution data sets. In Proceedings of EARSeL LISSIG Workshop, Observing our Cryosphere from Space, March 11-13, 2002, Bern, Switzerland. Paris, European Association of RemoteSensing Laboratories Special Interest Group Land Ice and Snow, $15-21$. 
Popovnin, V.V. 1995. Migratsiya ledorazdela na Dzhantuganskom firnovom plato [Ice divide migration along the Djantugan firn plateau]. Materialy glyatsiologicheskikh issledovaniy [Data of Glaciological Studies], 79, 123-127.

Popovnin, V.V. 1996. Modern evolution of the Djankuat glacier in the Caucasus. Z. Gletscherkd. Glazialgeol., 32, 15-23.

Popovnin, V.V. and R. Naruse. 2005. A 34-year long record of mass balance and geometric changes of the Djankuat Glacier, Caucasus. Bull. Glaciol. Res., 22, 113-125.

Popovnin, V.V. and A. Rozova. 2002. Influence of sub-debris thawing on ablation and runoff of the Djankuat Glacier in the Caucasus. Nord. Hydrol., 33, 75-94.

Rott, H. and G. Markl. 1989. Improved snow and glacier monitoring by the Landsat Thematic Mapper. In Proceedings of a Workshop on Earthnet Pilot Project on Landsat Thematic Mapper Applications, Frascati, Italy, December 1987. Noordwijk, , European Space Agency, 3-12.

Schneeberger, C., H. Blatter, A. Abe-Ouchi and M. Wild. 2003. Modelling changes in the mass balance of glaciers of the northern hemisphere for a transient $2 \times \mathrm{CO}_{2}$ scenario. J. Hydrol., 282, 145-163.

Serebryannyy, L.R., N.A. Golodkovskaya, A.V. Orlov, E.S. Malyasova and E.O. II'ves. 1984. Kolebaniya lednikov i protsessi morenonakopleniya na Tsentral'nom Kavkaze [Glacier variations and moraine accumulation: processes in central Caucasus]. Moscow, Nauka.
Seynova, I.B., V.V. Popovnin and Ye.A. Zolotaryov. 2003. Intensification of glacial debris flows in the Gerkhozhan River basin, Caucasus, in the late 20th century. Landslide News 14/15, $39-49$.

Shahgedanova, M., C.R. Stokes, S.D. Gurney and V.V. Popovnin. 2005. Interactions between mass balance, atmospheric circulation and recent climate change on the Djankuat glacier, Caucasus Mountains. J. Geophys. Res., 110(D4), D04108. (10.1029/2004JD005213.)

Solomina, O.N. 1999. Gornoe oledenenie Severnoi Evrazii v golotsene. Moscow, Moscow Scientific World.

Solomina, O.N. 2000. Retreat of mountain glaciers of northern Eurasia since the Little Ice Age maximum. Ann. Glaciol., 31, 26-30.

Volodicheva, N. 2002. The Caucasus. In Shahgedanova, M., ed. The physical geography of Northern Eurasia. Oxford, Oxford University Press, 350-376.

Williams, R.S., Jr, D.K. Hall, O. Sigurdsson and J.Y.L. Chien. 1997. Comparison of satellite-derived with ground-based measurements of the fluctuations of the margins of Vatnajökull, Iceland, 1973-92. Ann. Glaciol., 24, 72-80.

Wood, F.B. 1988. Global alpine glacier trends, 1960 s to 1980 s. Arct. Alp. Res., 20(4), 404-413.

Zolotaryov, Ye.A., V.V. Popovnin, A.S. Goretskiy and Ye.G. Kharkovets. 1997. Lednik Dzhankuat za posledniye 25 let [The Djankuat Glacier during the last 25 years]. Vestnik Moskovskogo Universiteta [Moscow Univ. Herald], ser. 5, 1, 24-30. 